\title{
ON GENERALIZATIONS OF OSTROWSKI INEQUALITY VIA SOME EULER-TYPE IDENTITIES
}

\author{
LJ. Dedić, M. MATić AND J. PEČARIĆ
}

Abstract. Some generalizations of Ostrowski inequality are given, by using some Euler-type identities.

Mathematics subject classification (1991): 26D15, 26D20, 26D99.

Key words and phrases: Ostrowski inequality, Bernoulli polynomials, bounded variation.

\section{REFERENCES}

[1] A. OSTROWSKI, Über die Absolutabweichung einer differentiebaren Funktion von ihren Integralmittelwert, Comment. Math. Helv. 10 (1938), pp. 226-227.

[2] V. I. KRYLOV, Approximate calculation of integrals, Macmillan, New York-London, 1962.

[3] M. ABRAMOWITZ AND I. A. STEGUN (Eds), Handbook of mathematical functions with formulae, graphs and mathematical tables, National Bureau of Standards, Applied Math.Series 55, 4th printing, Washington 1965.

[4] M. MATIĆ, J. PEČARIĆ AND N. UJEVIĆ, Improvement and further generalization of some inequalities of Ostrowski-Grüss type, Computers Math. Applic. 39 (2000), 161-175.

[5] M. MATIĆ, J. PEČARIĆ AND N. UJEVIĆ, Generalization of an inequality of Ostrowski type and some related results, Indian Jour. Math. (to appear).

[6] S. S. DRAGOMIR AND N. S. BARNETT, An Ostrowskitype inequality for mappings whose second derivatives are bounded and applications, The Journal of the Indian Mathematical Society (submitted) 